\title{
Ala67Thr Mutation in the Human Polio Virus Receptor (PVR) Gene in Post-Polio Syndrome Patients
}

\author{
Saurabh Kumar Bhattacharya ${ }^{1,3 *}$, Aditi Sarkar ${ }^{2}$ and Sonali Sengupta ${ }^{1}$ \\ ${ }^{1}$ Division of Biomolecules \& Genetics, School of Biosciences \& Technology, VIT University, Vellore, Tamilnadu, India \\ ${ }^{2}$ Functional Genomics and Cancer Biology Laboratory, VIT University, Vellore, Tamilnadu, India \\ ${ }^{3}$ Cytogenetics Department, Dr. Lal Path Labs Pvt. Ltd., National Research Laboratory, New Delhi, India
}

\begin{abstract}
Poliovirus (PV) has been implicated in the etiology of poliomyelitis. Post-polio syndrome (PPS) is a condition that affects polio survivor years after recovery from an initial acute attack of the polio virus. DNA polymorphisms in the poliovirus receptor gene (PVR) are associated with persistent poliovirus infection. In the present study we have presented clinical and demographic characteristics of the PPS individuals who were affected initially by poliomyelitis and later developed PPS. We have also attempted to find out whether mutation in the PVR gene allows poliomyelitis patients to progress for PPS. PVR mutation was studied in 110 cases of PPS and 200 normal controls. In PVR exon 2 , the Ala67Thr mutation was detected in $45.46 \%$ of progressive PPS and $10 \%$ of control subjects. The frequency of the mutation was significantly higher in patients with PPS than in controls. Changes in the PVR gene may result in slowly progressive cytopathic effects that may lead to progression of PPS.
\end{abstract}

Keywords: Poliovirus Receptor (PVR); Post-polio syndrome; Enterovirus

\section{Introduction}

Post-Poliomyelitis Syndrome or Post-Polio Syndrome (PPS) is the commonly accepted term to describe the neuromuscular symptoms, which may develop many years after acute paralytic poliomyelitis [1]. The existence of PPS has been questioned, but the delayed effect of poliomyelitis or PPS is generally accepted as a defined clinical entity [2,3]. Different studies of motor units of patients with PPS have revealed an ongoing denervation and reinnervation process $[4,5]$. PVR is related to the nectin family of adhesion molecules and expressed in intercellular junctions [6].

The involvement of virus in the progression of motor neuron disorders has long been suspected, especially since when poliovirus (a member of enteroviral family) was known to affect motor neuron selectively [7]. Recent studies shows existence of Enterovirus nucleic acids in the spinal cords of sporadic amyotrophic lateral sclerosis (ALS) more frequently as of controls [8-10]. An important aspect in the establishment of persistent Enterovirus infection is the viral receptor which is present in the cell surface [11]. Poliovirus share a common receptor known as polio virus receptor that belongs to immunoglobulin superfamily (CD 155;12). The human PV receptor (PVR), CD155, is a glycoprotein belonging to the immunoglobulin superfamily $[12,13]$. The PVR contains three extracellular immunoglobulin-like domains, a transmembrane like and cytoplasmic tail. It is known that antibodymediated immune responses are important for cellular effector functions, such as regulation of antibody production through receptor of the $\mathrm{F}_{c}$ part of immunoglobin $\mathrm{G}(\mathrm{F} c \gamma \mathrm{R})$ [14]. There was a significant correlation observed between $\mathrm{F}_{c} \gamma \mathrm{R}$ polymorphism and poliomyelitis [15]. PVR gene domain 1 (located in exon 2) confers susceptibility to PV infection [13].

It is known that PV is considered to be a lytic virus; it has been shown to persist in neuronal cell lines [16] as well as in the mouse nervous system [17]. We therefore investigated a group of patients with PPS to determine the frequency of these mutations and to understand the root cause for the development of PPS.

\section{Materials and Methods}

\section{Patient population and control subjects}

The entire cohort comprised 110 subjects. All met the diagnostic criteria for PPS giving a prevalence of $100.0 \%$. The prevalence rate was significantly higher in females $(56.36 \%)$ as compared to males $(43.64 \%)$. The mean age at the time of sampling was 39.65 years and the mean age at onset for the whole cohort was 24.63 months (median 12, range 3-84 months). The mean age at onset of PPS was 35.6 years (median 34, range 19-47.2 years). Muscle weakness represented the first symptom of PPS onset in $40.5 \%$ of patients, in $52.4 \%$ they started complaining muscle weakness and pain at the same time, and in $7.1 \%$ it followed pain (Tables 1 and 2). 200 male and female controls were collected who had an average age of 32.24 years. None of the controls had a history of any genetic or non-genetic diseases. None of the controls had a smoking habit as well.

\section{PVR genome analysis}

DNA from peripheral EDTA coated blood was extracted by a phenol-chloroform method [18]. The genomic sequence of PVR was obtained from Genbank (Accession no. X94226). The set of primer was designed as forward: 5'-GCCCCTCCCTATCTAGTCC-3' and the reverse: 5'-ATCCTCCCACCAAGTCTCTG-3' of exon 2 to amplify a 465 bp target including PVR exon 2 and its exon-intron junctions. Polymerase chain reaction (PCR) was carried out in a total volume of $50 \mu \mathrm{L}$ using $100 \mathrm{ng}$ genomic DNA, $0.4 \mu \mathrm{M}$ of each primer, $2.5 \mathrm{mM}$ of

*Corresponding author: Saurabh Kumar Bhattacharya, Deputy Head Cytogenetics Department, Dr. Lal Path Labs Pvt. Ltd., National Research Laboratory, Block E, Sector-19, Rohini, New Delhi, India, Tel: 011-30244157; E-mail: saurabh.bhattacharya@lalpathlabs.com

Received April 08, 2014; Accepted April 23, 2014; Published April 30, 2014

Citation: Bhattacharya SK, Sarkar A, Sengupta S (2014) Ala67Thr Mutation in the Human Polio Virus Receptor (PVR) Gene in Post-Polio Syndrome Patients. J Microb Biochem Technol 6: 185-188. doi:10.4172/1948-5948.1000141

Copyright: (C) 2014 Bhattacharya SK, et al. This is an open-access article distributed under the terms of the Creative Commons Attribution License, which permits unrestricted use, distribution, and reproduction in any medium, provided the original author and source are credited 


\begin{tabular}{|c|c|c|c|c|c|}
\hline Criteria & Affected by PPS & $P^{a}$ & Unadjusted OR (CI) & Adjusted OR (CI) & $P$ \\
\hline $\begin{array}{l}\text { Both Sexes } \\
\text { Male } \\
\text { Female }\end{array}$ & $\begin{array}{c}110 \\
48 \\
62\end{array}$ & 0.02 & $\begin{array}{l}1.00 \text { (reference) } \\
2.37(1.07-3.84)\end{array}$ & $\begin{array}{l}1.00 \text { (reference) } \\
1.57(0.72-2.88)\end{array}$ & 0.2 \\
\hline $\begin{array}{l}\text { Age at Onset of Poliob } \\
\leq 12 \text { months } \\
>12 \text { months }\end{array}$ & $\begin{array}{l}64 \\
46\end{array}$ & 0.01 & $\begin{array}{l}1.00 \text { (reference) } \\
0.32(0.16-0.82)\end{array}$ & $\begin{array}{l}1.00 \text { (reference) } \\
0.23(0.12-0.89)\end{array}$ & 0.02 \\
\hline $\begin{array}{l}\text { Number of affected muscles } \\
\leq 3 \\
>3\end{array}$ & $\begin{array}{l}38 \\
27\end{array}$ & 0.7 & $\begin{array}{l}1.00 \text { (reference) } \\
1.12(0.43-2.34)\end{array}$ & - & 0.4 \\
\hline $\begin{array}{l}\text { Number of affected functions }{ }^{c} \\
\leq 2 \\
>2\end{array}$ & $\begin{array}{l}28 \\
24\end{array}$ & 0.3 & $\begin{array}{l}1.00 \text { (reference) } \\
1.58(0.71-3.32)\end{array}$ & - & 0.9 \\
\hline $\begin{array}{l}\text { Eductaion (years of school) } \\
0-5 \\
6-8 \\
>9\end{array}$ & $\begin{array}{l}43 \\
27 \\
40\end{array}$ & 0.002 & $\begin{array}{l}1.00 \text { (reference) } \\
0.30(0.13-1.04) \\
0.23(0.07-0.57)\end{array}$ & $\begin{array}{l}1.00 \text { (reference) } \\
0.36(0.15-1.23) \\
0.21(0.07-0.69)\end{array}$ & 0.003 \\
\hline
\end{tabular}

aDifferences between subgroup frequencies are tested by chi ${ }^{2}$ analysis. Variables are dichotomised according to the median of the distribution in the whole cohort. ${ }^{\mathrm{b}} \mathrm{Age}$ at onset of poliomyelitis was unknown in one patient affected by PPS. Number of affected muscles and number of affected functions were unknown in four patients not affected by PPS. 'Education was unknown in two patients not affected by PPS

Table 1: Frequencies and risk estimates of clinical and demographic characteristics of patients with previous poliomyelitis, affected or not by PPS.

\begin{tabular}{|c|c|c|c|c|c|c|c|c|}
\hline Age (Yrs) & LLs $^{a}$ & RUL $^{b}$ & LULc $^{c}$ & ULs ${ }^{d}$ & $\mathbf{R L L}^{\mathrm{e}}$ & $\operatorname{LLL}^{f}$ & OTHER ${ }^{g}$ & TOTAL \\
\hline $15-20$ & 2 & 1 & 0 & 1 & 0 & 2 & 1 & 7 \\
\hline $21-25$ & 1 & 0 & 0 & 2 & 1 & 1 & 0 & 5 \\
\hline $26-30$ & 0 & 1 & 2 & 0 & 2 & 1 & 0 & 6 \\
\hline $30-35$ & 2 & 2 & 5 & 0 & 1 & 0 & 1 & 11 \\
\hline $36-40$ & 9 & 3 & 7 & 7 & 4 & 6 & 4 & 40 \\
\hline $41-50$ & 1 & 0 & 1 & 1 & 1 & 3 & 2 & 9 \\
\hline $51-55$ & 3 & 2 & 1 & 0 & 2 & 2 & 1 & 11 \\
\hline $55-60$ & 1 & 0 & 2 & 0 & 0 & 2 & 0 & 5 \\
\hline 61-65 & 1 & 1 & 1 & 1 & 1 & 2 & 1 & 8 \\
\hline $66-70$ & 0 & 1 & 1 & 0 & 2 & 2 & 2 & 8 \\
\hline Total & 20 & 11 & 20 & 12 & 14 & 21 & 12 & 110 \\
\hline
\end{tabular}

aLeft limbs, ${ }^{b}$ Right upper limb, 'Left upper limb, dUpper limbs, e Right left limb, f'Left lower limb, ${ }^{9}$ paralysis in other part of the body

Table 2: Age distribution and the severity in the PPS individuals.

total dNTPs, $1 \mathrm{U}$ Taq polymerase, $1 \mathrm{X}$ PCR buffer and $\mathrm{MgCl}_{2}$. Samples were denatured at $95^{\circ} \mathrm{C}$ for 2 min followed by 35 cycles of $95^{\circ} \mathrm{C}$ for 30 s, annealing at $55^{\circ} \mathrm{C}$ for $30 \mathrm{~s}$ and $72^{\circ} \mathrm{C}$ for 10 s. Final extension was at $72^{\circ} \mathrm{C}$ for 7 min. DNA was purified using QIAamp DNA Blood Mini kit (Qiagen, Hilden, Germany) according to the Blood and Body Fluid Spin protocol provided by Qiagen. Purified DNA was eluted into AE buffer (Qiagen) and stored at $-20^{\circ} \mathrm{C}$.

\section{Single strand confirmation polymorphism (SSCP) analysis}

SSCP was performed as per modified protocol of Orita et al. [19]. Samples were denatured at $95^{\circ} \mathrm{C}$ for 5 min and immediately placed on ice for $1 \mathrm{~min} .4 \mu \mathrm{L}$ of PCR product was loaded on $6 \%$ polyacrylamide gel. The electrophoresis was run at $80 \mathrm{v}$ for $5 \mathrm{~h}$. The gel was silver stained and viewed under gel documentation system (Biorad, USA).

\section{DNA sequencing}

All the amplicons were purified using DNA sequencing kit (Life technologies, USA). The products were directly sequenced to obtain typed DNA which could be used for DHPLC. The Big Dye terminator kit v3.1 was used for sequencing and fragments were characterized on an ABI PRISM 3700 DNA Analyzer.

\section{Results}

Tables 1 and 2 summarize the distribution of the investigated variables among persons with previous poliomyelitis. PPS was significantly higher among patients who had the onset of poliomyelitis before 12 months of age, and it was inversely associated with a higher education level. It was also observed that a significantly higher frequency of comorbid disorders in persons affected by PPS compared to polio survivors not affected by PPS.

The patients were of 15 years to 70 years at the time of sample collection. The age group ranges from 36-40 years were found to be most affected in our study. The major symptom of paralysis was found to be more prominent in LLs (Lower Limbs) as shown in Table 2. The minimal affected age group was found to be in 55-60 years age group i.e. 5. Table 2 also describes the age groups participated in the study and we have found the most affected age group was 36-40 years which is indicated as blue line and minimal which is 55-60 indicated as pink line.

The SSCP analysis of the PCR products of the exon 2 of PVR gene is shown in Figure 1A. Out of 110 patients, only 50 patients (45.46\%) showed polymorphism by SSCP in exon 2 of PVR gene. DNA sequence of PVR gene exon 2 revealed $\mathrm{G} \rightarrow \mathrm{A}$ mutation in 67 th locus of PVR exon 2 gene, resulting change in amino acid reading frame as Ala67Thr as shown in Figure 1C. The control subject showed no change in respective position of PVR gene (Figure 1B).

\section{Discussion}

The result from the present study shows that a polymorphism in 
the polio virus receptor is a possible risk factor for etiology of PPS. We have found that there was a possible conformational change present in PPS individual with respect to PVR exon 2 gene. This is in the contrast with the sequencing result which shows $\mathrm{G}>\mathrm{A}$ mutation (Ala67Thr). There were different studies present in the literature which supports our study, as presented in Table 3. As per previous studies done on PVR receptor [20-23], A/A homozygosity was not found. There might be two possibilities, one could be the lethality of homozygous mutation and another possibility is homozygous mutations are rare and failed to achieve in investigated population.

In spite of total 110 PPS cases were investigated, there are still limitations remains regarding mutation analysis of PVR. One relays to the association between Ala67Thr mutation and disease progression of PPS. We have investigated 110 cases of progressive PPS, in which 50 patients were found to have Ala67Thr mutation (Table 3). Saunderson et al. [22] have investigated 110 cases of ALS and they found $11.8 \%$ with Ala67Thr mutation which is lesser than us. The controls were also showed $5 \%$ of allelic frequency in our study whereas it was $6.8 \%$ in study done by Saunderson et al. [22] and Rosche et al. [21] has found highest frequency of mutation in controls (7.5\%) among all the studies listed in Table 3.

The mechanism by which Ala67Thr is associated with PPS is unknown. As per previous studies, Ala67Thr mutation was found to facilitate increased resistance against poliovirus-induced apoptosis or cell lysis [24,25]. Gromeier et al. has demonstrated that expression of CD155 is limited to spinal cord anterior horn motor neurons in transgenic mice [26]. Ala67Thr mutation can be used to obtain transgenic mice which would express CD155 receptors for understanding the pathogenesis of polio.

A univariate analysis risk for PPS showed a significant association

(A) PVR exon 2 polymorphism screening for Ala67Thr by SSCP

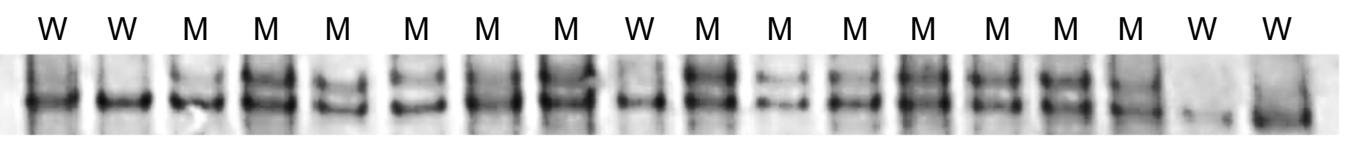

(B) DNA sequence showing Wild type (W) GCG in control

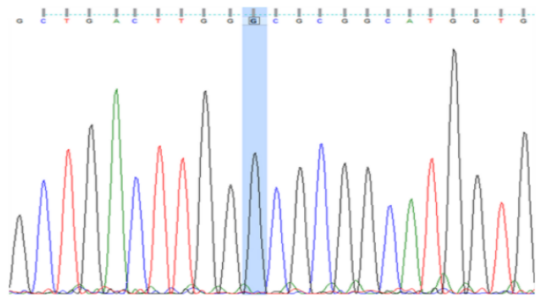

(C) DNA sequence showing Mutant (M) GCG $\rightarrow$ ACG (Ala67Thr) in PPS individuals

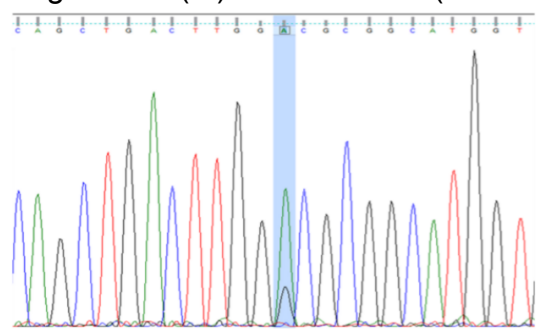

Figure 1: Mutation analysis for exon 2 of PVR gene.

(A) A SSCP analysis of PCR products of PVR exon 2 in PPS patients; $W$ refers to wild type and M as mutant.

(B) Wild type alleles in control individual with GCG.

(C) Mutant allele in PPS patients with GCG $\rightarrow$ ACG confirmation (highlighted refers to point of the mutation).

\begin{tabular}{|c|c|c|c|}
\hline Patient's Group & No. of Patients & Ala67Thr & References \\
\hline Post-Polio syndrome & 110 & $50(45.46 \%)$ & Present study \\
\hline Paralytic poliomyelitis & 6 & $1(16.7 \%)$ & [23] \\
\hline Amyotrophic lateral sclerosis (ALS) & 110 & $13(11.8 \%)$ & [22] \\
\hline Vaccine Associated Paralytic Poliomyelitis (VAPP) & 9 & $1(11.1 \%)$ & [23] \\
\hline Progressive muscular atrophy (PMA) & 30 & $6(20 \%)$ & {$[22]$} \\
\hline Controls & 200 & $10(5 \%)$ & Present study \\
\hline Controls & 280 & $19(6.8 \%)$ & [22] \\
\hline Controls & 56 & $4(7.1 \%)$ & [20] \\
\hline Controls & 493 & $37(7.5 \%)$ & {$[21]$} \\
\hline Total of all controls & 1029 & $70(6.8 \%)$ & \\
\hline
\end{tabular}

Table 3: Distribution of Ala67Thr mutation in the PVR gene among different study groups. 
Citation: Bhattacharya SK, Sarkar A, Sengupta S (2014) Ala67Thr Mutation in the Human Polio Virus Receptor (PVR) Gene in Post-Polio Syndrome Patients. J Microb Biochem Technol 6: 185-188. doi:10.4172/1948-5948.1000141

with the female sex and the presence of other disorders, while it was inversely associated with an onset of polio after 12 months of age and a higher educational level. Using multiple logistic regression analysis, it was observed that an inverse significant association between PPS and age at onset of polio after the first year of life and higher educational level, while a strong significant association between the presence of other diseases and PPS was also observed.

In conclusion, we have found that mutation in PVR gene may be associated with disease progression of PPS. It would be of great interest to find out exact mechanism playing role behind mutation of PVR gene and etiology of PPS after initial polio attack.

\section{Acknowledgement}

The authors are thankful to VIT University for providing excellent facilities to carry out this work. SKB is also thankful to the clinician and patients for participating in this study and provide relevant information.

\section{References}

1. Dalakas MC (1986) New neuromuscular symptoms in patients with old poliomyelitis: a three-year follow-up study. Eur Neurol 25: 381-387.

2. Farbu E, Gilhus NE, Barnes MP, Borg K, de Visser M, et al. (2006) EFNS guideline on diagnosis and management of post-polio syndrome. Report of an EFNS task force. Eur J Neurol 13: 795-801.

3. Trojan DA, Cashman NR (2005) Post-poliomyelitis syndrome. Muscle Nerve 31: $6-19$

4. Borg K (1996) Post-polio muscle dysfunction 29th ENMC workshop 14-16 October 1994, Naarden, the Netherlands. Neuromuscul Disord 6: 75-80.

5. Grimby G, Stålberg E, Sandberg A, Sunnerhagen KS (1998) An 8-year longitudinal study of muscle strength, muscle fiber size, and dynamic electromyogram in individuals with late polio. Muscle Nerve 21: 1428-1437.

6. Takahashi K, Nakanishi H, Miyahara M, Mandai K, Satoh K, et al. (1999) Nectin/PRR: an immunoglobulin-like cell adhesion molecule recruited to cadherin-based adherens junctions through interaction with Afadin, a PDZ domain-containing protein. J Cell Biol 145: 539-549.

7. Rosen DR, Siddique T, Patterson D, Figlewicz DA, Sapp P, et al. (1993) Mutations in $\mathrm{Cu} / \mathrm{Zn}$ superoxide dismutase gene are associated with familial amyotrophic lateral sclerosis. Nature 362: 59-62.

8. Woodall CJ, Riding MH, Graham DI, Clements GB (1994) Sequences specific for enterovirus detected in spinal cord from patients with motor neurone disease. BMJ 308: 1541-1543.

9. Berger MM, Kopp N, Vital C, Redl B, Aymard M, et al. (2000) Detection and cellular localization of enterovirus RNA sequences in spinal cord of patients with ALS. Neurology 54: 20-25.

10. Giraud P, Beaulieux F, Ono S, Shimizu N, Chazot G, et al. (2001) Detection of enteroviral sequences from frozen spinal cord samples of Japanese ALS patients. Neurology 56: 1777-1778.
11. Frisk G (2001) Mechanisms of chronic enteroviral persistence in tissue. Curr Opin Infect Dis 14: 251-256.

12. Mendelsohn CL, Wimmer E, Racaniello VR (1989) Cellular receptor for poliovirus: molecular cloning, nucleotide sequence, and expression of a new member of the immunoglobulin superfamily. Cell 56: 855-865.

13. Koike S, Horie H, Ise I, Okitsu A, Yoshida M, et al. (1990) The poliovirus receptor protein is produced both as membrane-bound and secreted forms. EMBO J 9: 3217-3224.

14. van der Pol W1, van de Winkel JG (1998) IgG receptor polymorphisms: risk factors for disease. Immunogenetics 48: 222-232.

15. Rekand T, Langeland N, Aarli JA, Vedeler CA (2002) Fcgamma receptor IIIA polymorphism as a risk factor for acute poliomyelitis. J Infect Dis 186: 18401843.

16. Colbère-Garapin F, Christodoulou C, Crainic R, Pelletier I (1989) Persistent poliovirus infection of human neuroblastoma cells. Proc Natl Acad Sci U S A 86: 7590-7594.

17. Destombes J, Couderc T, Thiesson D, Girard S, Wilt SG, et al. (1997) Persistent poliovirus infection in mouse motoneurons. J Virol 71: 1621-1628.

18. Miller SA, Dykes DD, Polesky HF (1988) A simple salting out procedure for extracting DNA from human nucleated cells. Nucleic Acids Res 16: 1215.

19. Orita M, Iwahana H, Kanazawa H, Hayashi K, Sekiya T (1989) Detection of polymorphisms of human DNA by gel electrophoresis as single-strand conformation polymorphisms. Proc Natl Acad Sci U S A 86: 2766-2770.

20. Karttunen A, Pöyry T, Vaarala O, llonen J, Hovi T, et al. (2003) Variation in enterovirus receptor genes. J Med Virol 70: 99-108.

21. Rosche B, Cepok S, Stei S, Vogel F, Grummel V, et al. (2004) The role of the polio virus receptor and the herpesvirus entry mediator $B$ genes for the development of MS. J Neuroimmunol 156: 171-177.

22. Saunderson R, Yu B, Trent RJ, Pamphlett R (2004) A polymorphism in the poliovirus receptor gene differs in motor neuron disease. Neuroreport 15: 383386

23. Kindberg E, Ax C, Fiore L, Svensson L (2009) Ala67Thr mutation in the poliovirus receptor CD155 is a potential risk factor for vaccine and wild-type paralytic poliomyelitis. J Med Virol 81: 933-936.

24. Pavio N, Couderc T, Girard S, Sgro JY, Blondel B, et al. (2000) Expression of mutated poliovirus receptors in human neuroblastoma cells persistently infected with poliovirus. Virology 274: 331-342.

25. Gosselin AS, Simonin Y, Guivel-Benhassine F, Rincheval V, Vayssière JL, et al. (2003) Poliovirus-induced apoptosis is reduced in cells expressing a mutan CD155 selected during persistent poliovirus infection in neuroblastoma cells. $J$ Virol 77: 790-798.

26. Gromeier M, Solecki D, Patel DD, Wimmer E (2000) Expression of the human poliovirus receptor/CD155 gene during development of the central nervous system: implications for the pathogenesis of poliomyelitis. Virology 273: 248257. 